\title{
Erosive processes after tectonic uplift stimulate vicariant and adaptive speciation: evolution in an Afrotemperate-endemic paper daisy genus
}

\author{
Joanne Bentley ${ }^{1 *}, \mathrm{G}$ Anthony Verboom ${ }^{1}$ and Nicola G Bergh ${ }^{2}$
}

\begin{abstract}
Background: The role of tectonic uplift in stimulating speciation in South Africa's only alpine zone, the Drakensberg, has not been explicitly examined. Tectonic processes may influence speciation both through the creation of novel habitats and by physically isolating plant populations. We use the Afrotemperate endemic daisy genus Macowania to explore the timing and mode (geographic versus adaptive) of speciation in this region. Between sister species pairs we expect high morphological divergence where speciation has happened in sympatry (adaptive) while with geographic (vicariant) speciation we may expect to find less morphological divergence and a greater degree of allopatry. A dated molecular phylogenetic hypothesis for Macowania elucidates species' relationships and is used to address the potential impact of uplift on diversification. Morphological divergence of a small sample of reproductive and vegetative characters, used as a proxy for adaptive divergence, is measured against species' range distributions to estimate mode of speciation across two subclades in the genus.

Results: The Macowania crown age is consistent with the hypothesis of post-uplift diversification, and we find evidence for both vicariant and adaptive speciation between the two subclades within Macowania. Both subclades exhibit strong signals of range allopatry, suggesting that geographic isolation was important in speciation. One subclade, associated with dry, rocky environments at high altitudes, shows very little morphological and ecological differentiation but high range allopatry. The other subclade occupies a greater variety of habitats and exhibits far greater morphological differentiation, but contains species with overlapping distribution ranges.

Conclusions: Species in Macowania are likely to have diversified in response to tectonic uplift, and we invoke uplift and uplift-mediated erosion as the main drivers of speciation. The greater relative morphological divergence in sympatric species of Macowania indicates that speciation in the non-sympatric taxa may not have required obvious adaptive differences, implying that simple geographic isolation was the driving force for speciation ('neutral speciation').
\end{abstract}

Keywords: Afrotemperate, Drakensberg, Uplift, Adaptive speciation, Vicariance, Gnaphalieae

\section{Background}

The formation of major mountain chains by tectonic uplift has stimulated plant diversification in many parts of the world, and the resulting diversity may be spectacular. Documented examples include the Andes [1-3], the Mexican Sierra Madre [4-6] and the Himalayas [7,8]. For example the northern Andes harbours some 45,000 plant species, $44 \%$ of which are endemic [9], with the northern Andean páramos topping this with $60 \%$ endemism [10].

\footnotetext{
* Correspondence: bntjoa002@myuct.ac.za

'University of Cape Town, Cape Town, South Africa

Full list of author information is available at the end of the article
}

However, the specific mechanisms by which uplift may influence species divergence have seldom been explicitly explored. In this study, we examine the mechanisms underlying speciation following uplift of a diverse South African mountain system.

In southern Africa, Pliocene tectonic uplift played a major role in creating the geomorphically diverse Drakensberg ('Dragon's Mountain') range [11-14]. The Drakensberg constitutes the higher, eastern façade of the central plateau ('the Great Escarpment') of South Africa (Figure 1). In terms of both height and endemic plant diversity, the Drakensberg is more modest than the Andes, with a maximum altitude of $3,482 \mathrm{~m}$ and the core area hosting

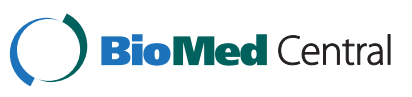




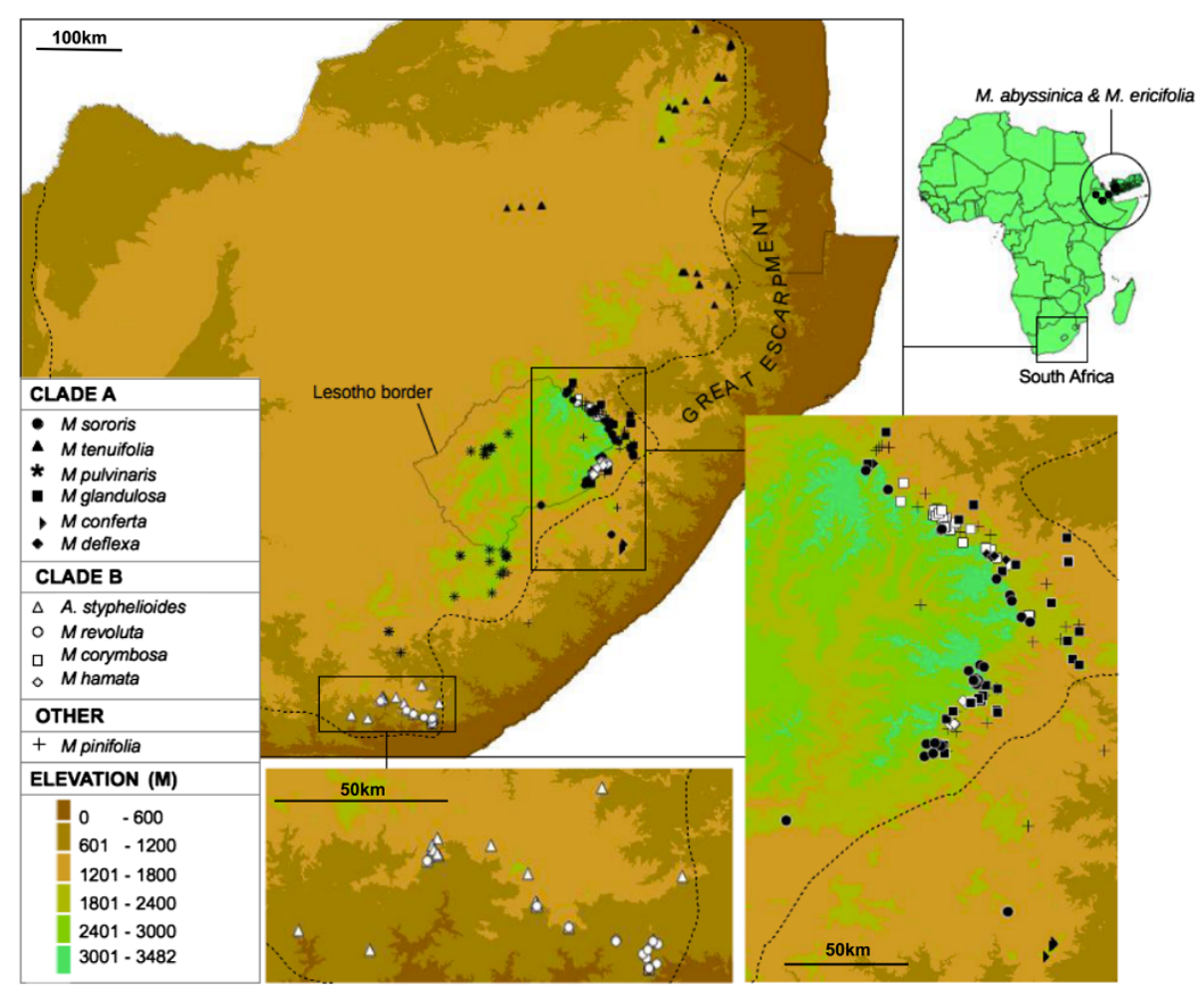

Figure 1 Distribution map of Macowania and Arrowsmithia. Clade A species are indicated by black symbols, clade B species by white symbols. The dotted line represents the Escarpment edge. The disjunct distributions of M. abyssinica and M. ericifolia in the East African highlands and Yemen are indicated at the top right of the figure. Insets of selected parts of the distribution in South Africa are provided for small areas that house multiple species.

ca 2,520 species or subspecies of flowering plants, of which $16 \%$ are endemic [15]. Nevertheless, the Drakensberg region is one of three centres of Afrotemperate endemism, and appears to have been an important link between the centre in the Ethiopian highlands and that in the highly diverse Cape region with dispersal in both directions resulting from, and possibly facilitating, floristic radiations (e.g. northwards after radiation: Disa, Irideae, Pentachistis, Restionaceae [16]; southwards: Scabiosa [17]; Erica [18]). Within the mega-diverse southern African subregion, the Drakensberg constitutes the highest-lying land and the only true alpine habitat $[19,20]$. The endemic Drakensberg flora is thus directly or indirectly a product of the tectonic processes that created these high-altitude habitats.

Tectonic uplift might stimulate speciation in two principal ways. First, pronounced uplift will produce a novel, high-altitude adaptive zone which may serve as an arena for adaptive radiation (sensu Simpson [1]). The scale of radiation that occurs within such an adaptive zone will ultimately depend on the heterogeneity of habitats on offer, but this is likely to be high owing to the effectiveness of tectonism and subsequent erosion in generating situations that vary in terms of altitude, aspect, slope, geology, soil type, microclimate and moisture regime (e.g. stream beds versus rocky ridges). Underlying geological heterogeneity will increase the overall habitat diversity by allowing for specialisation to different soil types as they are exposed or created by erosion; it will also result in a more complex landscape due to differences in erodibility. Tectonism may also promote species radiation indirectly, by the stimulation of large-scale erosion resulting from increased river gradients. Removal of increasing portions of the landscape will disrupt the original land surface, potentially fragmenting species ranges. Given time, populations separated by erosion gaps will diverge as a consequence of both adaptive divergence and neutral processes (drift), the latter being more important where the selective differentials between populations are low and/or population size is small with limited gene flow [21]. An example of neutral divergence following erosion-mediated habitat fragmentation is the divergence of a montane lizard genus (Phrynosoma) in the Sierra Madre of Mexico, where canyon formation followed tectonic uplift [4-6]. Although the potential importance of non-adaptive divergence as a driver of speciation (non-ecological speciation) is gaining recognition [22-24], the long-standing emphasis on adaptive divergence as the sole agent remains pervasive [25-28], and it is difficult to prove the absence of any form of adaptation. 
In principle, post-uplift species accumulation is likely to occur as a consequence of both adaptive and nonadaptive processes. If this is true, tectonic processes and subsequent erosion have likely been important as stimuli for both adaptive and non-adaptive diversification in the Drakensberg. One of the predictions of this hypothesis is that the bulk of diversification in endemic lineages should be associated with (or occur soon after) episodes of major tectonic activity. Also, where non-adaptive processes have been important, we expect to find strong signatures of allopatric speciation, paired with limited functional divergence. A brief overview of the geological history of the region reveals high probability of erosion-mediated range fragmentation. Composed of large blocks of sedimentary and volcanic rocks (primarily the soft 'cave' sandstones of the Clarens group topped by the younger and erosion-resistant basalts and dolerites of the Drakensberg group) which have been deposited over the past 200 $\mathrm{Ma}$, the highly incised contemporary landscape of the Drakensberg is a product of erosion associated with cyclical uplift throughout the Cenozoic. Following the separation of Africa from the rest of Gondwanaland at about $184 \mathrm{Ma}$, the eastern half of South Africa experienced several cycles of uplift. The two most recent cycles, the first occurring in the early Miocene and the second in the early Pliocene $( \pm 5 \mathrm{Ma})$, are thought to have raised the eastern margin of the Great Escarpment of southern Africa by between $150-300 \mathrm{~m}$ and $600-900 \mathrm{~m}$ respectively [12,14,29-31], each cycle stimulating renewed erosion [11-13]. Over time, the resulting escarpment edge, originally a uniform plateau extending to nearly the present-day coastline [11], is hypothesised by some authors [11-13] to have eroded back towards the interior of the country, simultaneously being incised by a series of deep drainage gulleys. The greater elevations of the Drakensberg range, relative to the rest of the Great Escarpment, has been attributed to pronounced upward flexing in response to to local intense erosion on one flank [32-34]. In the absence of historical volcanism, the contemporary deeply-dissected and geologically heterogeneous Drakensberg landscape is thus a product of landscape erosion.

The existence of the Drakensberg has undoubtedly been key to the creation of the 'Afrotemperate track' $[20,35,36]$, a continuous zone of floristic affinity between the hyperdiverse Cape Floristic Region and the Afrotemperate regions of tropical Africa and the Mascarenes [37]. Dispersal both to and from the Cape via the Drakensberg may have been an important factor in the genesis of Afrotemperate plant diversity, including the floras of Madagascar and upland tropical Africa, as well as providing opportunities for European alpine lineages to disperse to and subsequently diversify in the Cape. Regional floras are assembled via both immigration and in situ diversification. Most
Drakensberg-endemic lineages studied to date appear to be the result of repeated independent dispersal into the region, rather than in situ diversification [16]. Evidence for this lies in the low number of endemic species per genus. Of the 37 genera that contribute more than three endemic species to the Drakensberg Alpine Centre (DAC: the central, highest-lying part of the Drakensberg range $[38,39]$ ), only two have more than 12 endemics and the average is 6 endemic species [40]. Although the scale of in situ radiation varies among Drakensberg plant lineages [16] it appears for the most part to be modest, which may reflect both a youthful colonisation history and the small scale of the region. The daisy family Asteraceae has been the most successful angiosperm coloniser of the Drakensberg, with several genera contributing high numbers of endemic species to the DAC (Helichrysum: 29; Senecio: 22; Euryops: 7 [38]).

The paper daisy genus Macowania Oliver has five species strictly endemic to the DAC, but ten species endemic to the greater Drakensberg area (including the escarpment of the Eastern Cape, KwaZulu-Natal and Mpumalanga provinces). This makes it comparatively species-rich, and an excellent system for exploring the impact of landscape evolution on speciation in the greater Drakensberg area. In total, Macowania comprises 12 evergreen, woody subshrubs, the two non-Drakensberg species being native to the highlands of Ethiopia, Djibouti, Eritrea and Yemen (henceforth referred to as 'East Africa'; Figure 1) and comprising the northern extent of the typical 'Afrotemperate track' [35]. The South African species of Macowania are essentially restricted to high-elevation habitats, the majority favouring rocky environments along or immediately below the Drakensberg scarp edge. Here they inhabit a diversity of substrata or geologies, and some degree of substrate-specificity is apparent. Three species are unusual in preferring riparian or frequently-moist habitats.

In this study, we present a dated molecular (nuclear and plastid DNA) phylogenetic hypothesis for Macowania and, in conjunction with distributional and morphological data, use this to explore speciation pattern and process. We include in our study the monotypic genus Arrowsmithia because, despite its contrasting vegetative morphology, past authors have suggested the possibility of a close relationship with Macowania [41,42]. In view of the overwhelming association of Macowania with highelevation habitats, we hypothesise that the Drakensberg species of Macowania constitute a clade whose contemporary diversity is the product of a minor radiation associated with dramatic Pliocene uplift of the Drakensberg scarp. Our discovery within Macowania of two principal clades, one restricted to more-or-less uniform highelevation rocky habitats (clade A) and the other occupying a broader array of ecological situations (clade B, occurring on rocky slopes, along streams and in seepages), indicates 
a potential role for both non-ecological and ecological speciation processes (Figures 1 and 2). We speculate that, whereas erosion-induced fragmentation of the scarp zone has resulted in a history of primarily vicariant speciation in clade $\mathrm{A}$, speciation in clade $\mathrm{B}$ has been powered to a greater extent by adaptive divergence. To evaluate these ideas, we test the predictions that, consistent with a vicariant speciation model, (i) the signatures of allopatric speciation should be stronger in clade A than in clade B; (ii) morphological divergence, used as a proxy for functional diversification, should be less pronounced in clade A than in clade B; and (iii) where related species have highly overlapping distributions, especially in clade B, morphological divergence should be higher. We also use molecular dating to evaluate the hypothesis that radiation of these clades closely followed recent tectonic uplift at the start of the Pliocene.

\section{Methods}

\section{Species collection and sampling}

Between one and four accessions of all known species of Macowania and Arrowsmithia were sampled, resulting in a total of 34 ingroup individuals. We also included a single accession of each of the closely-related outgroup genera $[43,44]$ (Table 1). More distant outgroups (Galeomma and Ifloga) represent early-diverging lineages of the 'crown radiation' of Gnaphalieae $[45,46]$. Leaf material was collected in the field and/or sampled from herbarium specimens from BOL, PRE, K, GRA or NU. While a large proportion of the available herbarium material yielded poor DNA, sequences from multiple accessions were nevertheless obtained for all species except $M$. ericifolia from East Africa (represented by a single accession).

\section{DNA extraction and sequencing}

Total genomic DNA was isolated from silica-dried, fieldsampled material using the CTAB extraction protocol of [47] modified according to [48], while the Qiagen DNeasy plant extraction-kit (Qiagen Sciences, Valencia, California, U.S.A.) was used for herbarium material. Two nuclear and two plastid regions with proven phylogenetic utility in Gnaphalieae were utilised [43,45,49]. The 3' end of the external transcribed spacer (ETS) of nuclear ribosomal DNA was amplified using the primers 18S-ETS [50] and AST-1 [51] while the associated ITS1 and ITS2 introns and the intervening $5.8 \mathrm{~S}$ ribosomal gene were amplified as a unit using the ITS4 and ITS5 primers of [52]. For the chloroplast genome, the trnTtrnL spacer was amplified using the primers 'trna' and 'trnb' of [53] and the psbA-trnH spacer was amplified with the trnH-R and psbA-F primers of [54].

PCR was performed in an Applied Biosystems 2720 thermal cycler (Applied Biosystems CA, USA) with the following thermal profile: initial denaturation of two
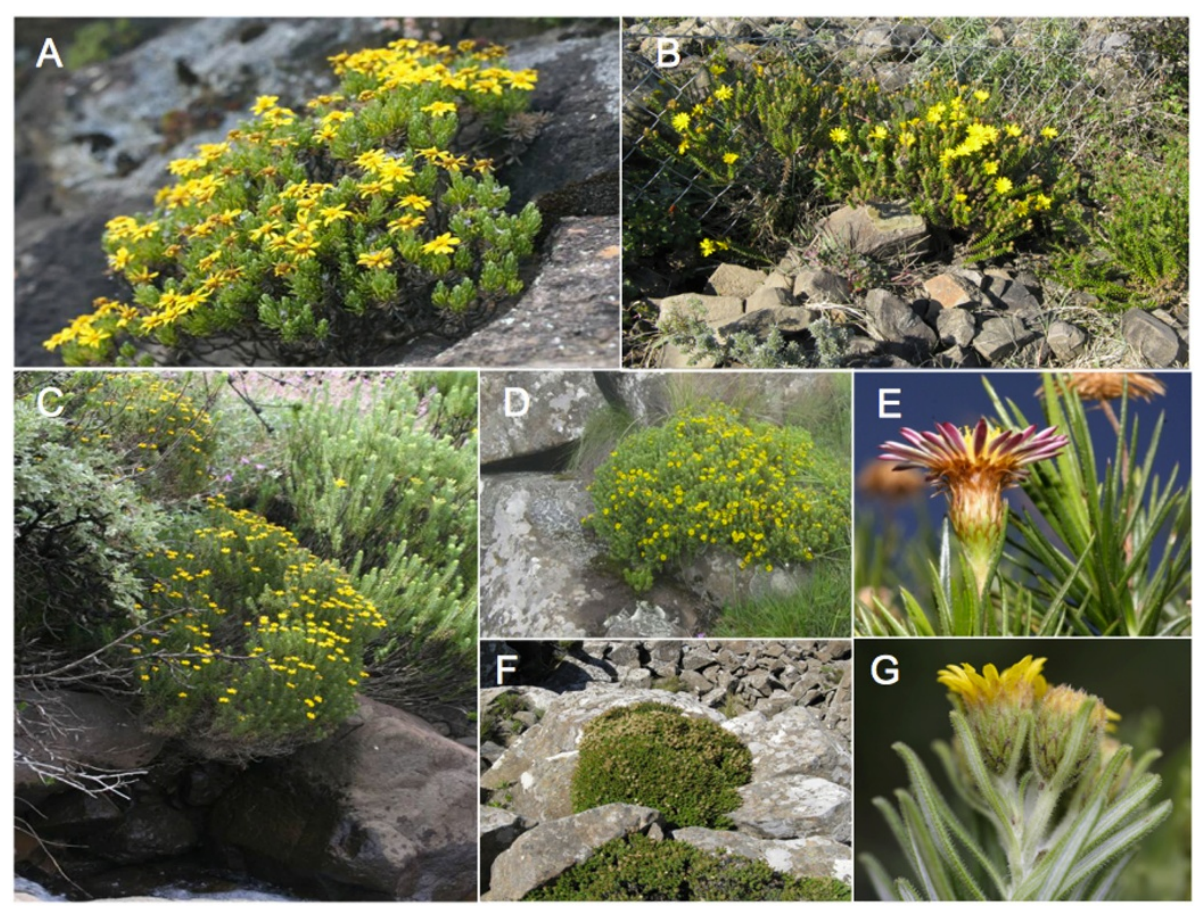

Figure 2 Habitat, habit and morphology of selected study species. A: M. pulvinaris (clade A). B: Arrowsmithia styphelioides (clade B). C: M. hamata, overhanging a stream (clade B). D: M. conferta with cushioned growth form (clade A). E: M. pinifolia, unusual in Macowania due to its pink ray florets and non-revolute leaves. F: Habitat of $M$. sororis cushioned among dolerite rocks/boulders (clade A). G: Typical Macowania inflorescence and leaves of $M$. corymbosa (clade A), also showing the dark-edged bracts shared by R. revoluta and M. corymbosa. 
Table 1 Sampling table of all species accessions used in this study

\begin{tabular}{|c|c|c|c|c|c|c|}
\hline \multirow[t]{2}{*}{ Species name } & \multirow{2}{*}{$\begin{array}{l}\text { Voucher details } \\
\text { Collector \& herbarium }\end{array}$} & \multicolumn{4}{|c|}{ GenBank accession number } & \multirow[t]{2}{*}{ Geographic origin } \\
\hline & & ITS & ETS & $\operatorname{trnT}-\mathrm{L}$ & psbA-trnH & \\
\hline Arrowsmithia styphelioides & Bergh 2188 (NBG) & KF997177 & KF997221 & KF997136 & KF997108 & Mount Kempt \\
\hline A. styphelioides & Bergh 2129 (NBG) & KF997178 & KF997222 & KF997135 & - & Katberg Pass \\
\hline A. styphelioides & O Hilliard \& B Burtt 13266 (NU) & KF997179 & KF997223 & - & - & Katberg Pass \\
\hline Athrixia angustissima & M Koekemoer 3550 (PRE) & KF997172 & - & KF997131 & - & Sehlabathebe National Park \\
\hline A. arachnoidea & NG Bergh 2198 (NBG) & KF997173 & - & KF997132 & KF997105 & Cathedral Peak \\
\hline A. elata & NG Bergh 2203 (NBG) & KF997174 & - & KF997133 & KF997106 & Pilgrims Rest \\
\hline A. fontana & M Koekemoer 3554 (PRE) & KF997175 & - & KF997134 & - & Sehlabathebe National Park \\
\hline A. phylicoides & NG Bergh 2180 (NBG) & KF997176 & KF997220 & - & KF997107 & Cathedral Peak \\
\hline Comborhiza virgata & NG Bergh 2174 (NBG) & KF997180 & KF997224 & KF997137 & KF997109 & Injusuthi \\
\hline Galeomma oculus-cati & NG Bergh 1703a (NBG) & - & FR821616 & FR821716 & - & Western Cape \\
\hline Ifloga spicata & J Lambinon 17590 (NBG) & - & FR821628 & FR821728 & - & Western Cape \\
\hline Leysera leyseroides* & Lippert 22077 (PRE) & KF997181 & - & KF997138 & - & Morocco \\
\hline Macowania abyssinica* & Friis et al. $12210(\mathrm{~K})$ & KF997182 & - & KF997139 & - & Ethiopia \\
\hline M. abyssinica* & Polunin $11650(K)$ & KF997183 & - & - & - & Ethiopia \\
\hline M. conferta & NG Bergh 2245 (NBG) & KF997184 & KF997225 & KF997140 & KF997121 & Mount Ngeli \\
\hline M. conferta & NG Bergh 2246 (NBG) & KF997185 & KF997226 & KF997141 & - & Mount Ngeli \\
\hline M. corymbosa & J Bentley 002 (NBG) & KF997186 & KF997227 & KF997142 & KF997115 & Cathedral Peak \\
\hline M. corymbosa & ARA Noel 1672 (GRA) & KF997188 & - & - & - & Sinyazi \\
\hline M. corymbosa & NG Bergh 2177 (NBG) & KF997187 & KF997228 & KF997143 & KF997110 & Injusuthi \\
\hline M. deflexa & NG Bergh 2173 (NBG) & KF997189 & KF997229 & KF997144 & KF997111 & Injusuthi \\
\hline M. deflexa & NG Bergh 2178 (NBG) & KF997190 & KF997230 & KF997145 & - & Injusuthi \\
\hline M. ericifolia* & Miller 3133 (K) & KF997191 & - & KF997146 & - & Yemen \\
\hline M. glandulosa & NG Bergh 2181 (NBG) & KF997192 & KF997231 & KF997147 & KF997112 & Cathedral Peak \\
\hline M. glandulosa & O Hilliard \& B Burtt 17984 (NU) & KF997193 & KF997232 & - & KF997124 & Sani pass \\
\hline M. hamata & JP Roux 1826 (NBG) & KF997194 & KF997233 & KF997148 & - & Sani Pass \\
\hline M. hamata & NG Bergh 2166 (NBG) & KF997195 & KF997234 & KF997149 & KF997113 & Sani Pass \\
\hline M. hamata & CJ Ward 10145 (PRE) & KF997196 & KF997235 & KF997150 & KF997114 & Sani Pass \\
\hline M. pinifolia & J Bentley 003 (NBG) & KF997197 & KF997236 & KF997151 & KF997116 & Royal Natal Drakensberg \\
\hline M. pinifolia & J Bentley 004 (NBG) & KF997198 & KF997237 & - & KF997117 & Royal Natal Drakensberg \\
\hline M. pinifolia & MP Robertson 74 (PRE) & KF997199 & KF997238 & KF997152 & KF997118 & Sani Pass \\
\hline M. pinifolia & TD Abbot 7875 (PRE) & KF997200 & KF997239 & KF997153 & KF997119 & Garden castle forest reserve \\
\hline M. pulvinaris & JE Victor 1569 (PRE) & KF997201 & KF997240 & KF997154 & KF997123 & Barkly East \\
\hline M. pulvinaris & M Koekemoer 1581 (PRE) & KF997202 & KF997241 & KF997155 & KF997122 & Rhodes \\
\hline M. pulvinaris & NG Bergh 2140 (NBG) & KF997203 & KF997242 & KF997156 & - & Naudes Nek Pass \\
\hline M. revoluta & J Bentley 001 (NBG) & KF997204 & KF997243 & - & - & Evelyn Valley Forestry Station \\
\hline M. revoluta & J Bentley 005 (NBG) & KF997205 & KF997244 & KF997157 & KF997120 & Evelyn Valley Forestry Station \\
\hline M. sororis & TR Green 1237 (NU) & KF997206 & KF997245 & KF997158 & KF997126 & Sani Pass \\
\hline M. sororis & FK Hoener 1714 (NU) & KF997207 & - & - & - & Sehlabathebe National Park \\
\hline M. sororis & NG Bergh 2161 (NBG) & KF997208 & KF997246 & KF997159 & KF997125 & Mount Currie \\
\hline M. tenuifolia & M Koekemoer 2079 (PRE) & KF997209 & - & KF997160 & KF997127 & Mount Sheba \\
\hline M. tenuifolia & M Koekemoer 2100 (PRE) & KF997210 & KF997247 & KF997161 & KF997128 & Mashishing \\
\hline M. tenuifolia & NG Bergh 2211 (NBG) & KF997211 & KF997248 & KF997162 & KF997129 & Mount Sheba \\
\hline Oedera genistifolia & NG Bergh 1572 (NBG) & KF997212 & KF997249 & KF997163 & - & Grahamstown \\
\hline
\end{tabular}


Table 1 Sampling table of all species accessions used in this study (Continued)

\begin{tabular}{lllllll}
\hline O. steyniae & NG Bergh 1762 (NBG) & KF997213 & KF997250 & KF997164 & - & Vermaaklikheid \\
$\begin{array}{l}\text { O. uniflora } \\
\text { Pentatrichia petrosa* }\end{array}$ & NG Bergh 1597 (NBG) & KF997214 & KF997251 & KF997166 & - & Napier \\
Relhania acerosa & E Klaasen 2143 (WIND) & FR832509 & FR823348 & FR832580 & - & Namibia \\
$\begin{array}{l}\text { R. dieterlenii } \\
\text { R. rotundifolia }\end{array}$ & NG Bergh 2137 (NBG) & KF997215 & KF997252 & KF997167 & - & Naudes Nek Pass \\
$\begin{array}{l}\text { Rhynchopsidium sessiliflorum } \\
\text { Rosenia humilis }\end{array}$ & NG Bergh 2148 (NBG) & KF997216 & KF997253 & KF997168 & KF997130 & Rhodes \\
\hline
\end{tabular}

All samples were collected in South Africa, except those indicated by*.

minutes at $94^{\circ} \mathrm{C} ; 35$ cycles consisting of $94^{\circ} \mathrm{C}$ for $45 \mathrm{sec}$, $52^{\circ} \mathrm{C}$ for $45 \mathrm{sec}$ (annealing) and $72^{\circ} \mathrm{C}$ for two min (extension); and a final extension step of $72^{\circ} \mathrm{C}$ for eight min. Reaction mixtures consisted of $12.8 \mu \mathrm{l}$ nuclease-free $\mathrm{H}_{2} \mathrm{O}, 2.5 \mu \mathrm{l}$ of 10x buffer (Kapa Biosystems Inc., MA, USA), $1.5 \mu \mathrm{l}$ of $25 \mu \mathrm{M} \mathrm{MgCl}, 1 \mu \mathrm{ldNTP}$ mix at $0.2 \mu \mathrm{M}$ each dNTP, $0.5 \mu \mathrm{l}$ DMSO, $1.25 \mu \mathrm{l}$ of each primer at $10 \mu \mathrm{M}, 0.2 \mu \mathrm{l}$ of Taq DNA polymerase (Kapa Biosystems Inc., MA, USA) and $4 \mu \mathrm{l}$ of template DNA at various dilutions. Successfully amplified products were, for the most part, cleaned and sequenced by Macrogen (Macrogen Inc, Korea), who employed BigDye terminator cycling, using the amplification primers, with an ABI Automated Sequencer $3730 \mathrm{XL}$ being used to visualise the products (Life Technologies Corporation, Carlsbad, California, U.S.A.). Some products were, however, submitted to the Central Analytical Facility at Stellenbosch University, South Africa, where they were sequenced using a 3130XL Genetic Analyzer/3730 Genetic Analyzer. Chromatograms were assembled, examined and corrected where necessary using Geneious Pro v 5.4.4 (Biomatters Ltd., 2011) and manually aligned using BioEdit v 7.1.3.0 [55].

\section{Phylogenetic analysis}

Indels were treated as missing data in all analyses. For the individual nuclear and plastid analyses the dataset was pruned to include only taxa that are represented by the relevant gene region. To check for topological incongruence, the four DNA regions were first analysed individually, and support for recovered clades evaluated using the parsimony bootstrap [56] in PAUP v 4.0 [57]. Although subject to dataset-specific biases and potentially problematic under certain conditions (e.g. long-branch attraction, lack of support on short internodes: [58,59]), the bootstrap is a relatively conservative measure of topological support [60]. One thousand bootstrap replicates were performed using only parsimony-informative sites, with tree bisection-reconnection (TBR) branch swapping on 100 random-addition trees with the multrees option not in effect and saving 100 trees per random-addition replicate. Trees were rooted on G. oculus-cati and $I$. spicata. Individual bootstrap consensus trees were examined for conflicting nodes supported by bootstrap percentages of $75 \%$ or higher. Since no such nodes were found, the datasets were concatenated, and a parsimony analysis of the combined data executed with the same settings.

The combined data (including those taxa represented by only nuclear or only plastid data) were also analysed using Bayesian phylogenetic inference, as implemented in MrBayes v 3.1.2 [61]). For this purpose, MrModeltest v 2.2 [62] was used to determine the optimal available models of DNA evolution under the AIC criterion [63]. This identified the GTR + G model as optimal for ITS, the GTR + I + G model for ETS and the GTR model for both plastid regions. A mixed model approach was employed in which substitution model parameters were estimated separately for each of three data partitions: (i) ETS, (ii) ITS and (iii) a combined plastid partition (all genes in the chloroplast genome are linked and should share the same phylogenetic history) using a Metropoliscoupled Markov Chain Monte-Carlo (MCMCMC) sampling procedure. Two concurrent analyses were run for $10^{7}$ generations each, starting with a different random tree and with parameters being sampled every 1,000 generations. The chain heating parameter was set at 0.3 and apart from the model settings, the default settings were retained. This analysis was repeated three times resulting in an overall total of six independent runs.

Convergence and stationarity were examined using the average standard deviation of split frequencies as output by MrBayes. The tree topologies from the six independent runs were also compared to check whether the runs were converging on the same topology. Convergence was further tested in Tracer v 1.3 [64] where the parameter estimates, ESS scores and likelihood traces were examined. Using the above checks, we discarded the first $10 \%$ of samples from each run as burn-in.

\section{Estimation of lineage divergence times}

Divergence times were estimated using an uncorrelated relaxed lognormal Bayesian clock as implemented in BEAST v 1.6.2 [64], the input data being configured using 
BEAUTi v 1.6.1 [64] (BEAST .xml file available on request from the corresponding author). A paucity of fossil data renders molecular clock calibration difficult in Asteraceae, forcing us to employ a secondary calibration procedure. For this purpose, we made use of two nodes dated by Bergh and Linder [40] (Nodes B [Gnaphalieae crown age] and $\mathrm{K}$ [Relhania clade crown age]). To account for the compounding of error associated with secondary calibration (e.g. [65]), the priors on the two calibration nodes were specified in such a ways as to incorporate the uncertainty associated with Bergh and Linder's [40] posterior age estimates. In each case, this was done by setting the mean and $95 \% \mathrm{CI}$ of the normal prior to be equal to the mean and 95\% HPD estimates reported by Bergh and Linder. The relaxed clock analysis employed a Yule tree prior and a mixed-model approach in which the sequence partitions and their associated models of nucleotide substitution were specified as for the MrBayes analysis. Two MCMC chains were run for $3 \times 30^{7}$ generations each, with sampling every 1,000 generations. The results of these runs were tested for convergence as described above, and the runs were combined using LogCombiner $\mathrm{v}$ 1.6.2, again discarding the first ten percent of each sample as burn-in. The maximum clade credibility tree, with median node ages, was then extracted using TreeAnnotator v 1.6.2 [64].

\section{Range overlap}

To measure pairwise range overlap, species' ranges were estimated by plotting point locality data and calculating convex hull polygons. The localities of all relevant specimens at five South African herbaria (NBG, BOL, PRE, PRU, NU), as well as field observations by the authors were geo-referenced as precisely as possible using 1:50,000 topographic maps (Chief Directorate: Surveys \& Mapping, Mowbray, Cape Town) in an ArcMap 10 environment (ArcGIS Desktop 10 Service Pack 2: CA: ESRI), as well as Google Earth and Google Maps. Where recorded, GPS co-ordinates provided a precise indication of locality. Convex hull polygons (i.e. the polygon that would be created by placing a tightly-stretched elastic band around all the point localities for a species) were produced using the 'clusthr' command in the 'adehabit' package [66] in R v 2.15.1 (R Development Core Team 2008). Convex hulls yield simplistic estimates of species' ranges, ignoring range discontinuities and irregularities in range boundaries. Nonetheless, they are likely to closely approximate the ranges of species that have compact, continuous distributions, as is typical for Macowania and Arrowsmithia. In addition, the fact that this method overestimates the extent of geographic ranges renders it a conservative measure of allopatry, making it robust for our purpose. Since convex hulls are sensitive to spatial errors [67], every effort was made to check and correct specimen identifications and locality information, and doubtful localities were excluded. Nevertheless, for several taxa very few precise localities were available and we had to use some observations that we deemed were accurate only to the nearest $5,001-10,000 \mathrm{~m}$, the minimum number of locality points being six for the local endemic $M$. deflexa. Once the polygons were defined, the nested average of range overlaps between species was calculated as per Fitzpatrick and Turelli [68] using the BEAST tree topology, trimmed of multiple species accessions.

\section{Testing for adaptive differentiation}

Adaptive divergence in montane settings could be driven by a range of selective forces, acting alone or in combination (for example, specialisation to particular climatic or edaphic niches or to different pollinators). As a proxy for adaptive differentiation, we looked for a suite of vegetative and reproductive characters that were relatively uniform within species of the core Macowania clade, but able to fairly reliably differentiate amongst species. Our rationale was that characters showing such patterns are likely to be under selection, or linked to other traits that are under selection. The characters selected were capitulum length and width (relating to reproduction, including floral display, seed size and number and seed protection) and leaf length and width (shown to be strongly correlated with plant habitats [69]). Precision callipers were used to measure 20 specimens per species, choosing representatives from across the geographic range of each. Owing to limited numbers of herbarium specimens, fewer measurements were taken for the localised endemics $M$. deflexa (two specimens), and M. conferta (six), as well as for $M$. hamata (14) and M. revoluta (18). For each character, the measurements from all specimens of a species were averaged and input into a pairwise multivariate discriminate functions analysis (DFA), as implemented in R v 2.15.1. Mahalanobis' [70] distance, widely used in biological clustering, was then calculated between species. Mahananobis' distance uses both the mean and variance of the predictor variables, as well as the covariance matrix of the variables, thus taking advantage of the covariance among variables. By transforming measurements into standardised uncorrelated data which is used to estimate Euclidean distances, scale differences are taken into account when estimating distances.

\section{Results}

\section{Phylogenetic relationships in Macowania}

The two nuclear regions (ETS \& ITS) produced completely congruent trees, and so were combined to form a single nuclear matrix consisting of 47 accessions and 1,092 aligned nucleotides, of which 433 (40\%) characters were parsimony-informative (Figure 3). Similarly, the two plastid regions (trnT-L and $p s b A-F)$ yielded poorly-resolved but congruent trees, and were combined to form a matrix 


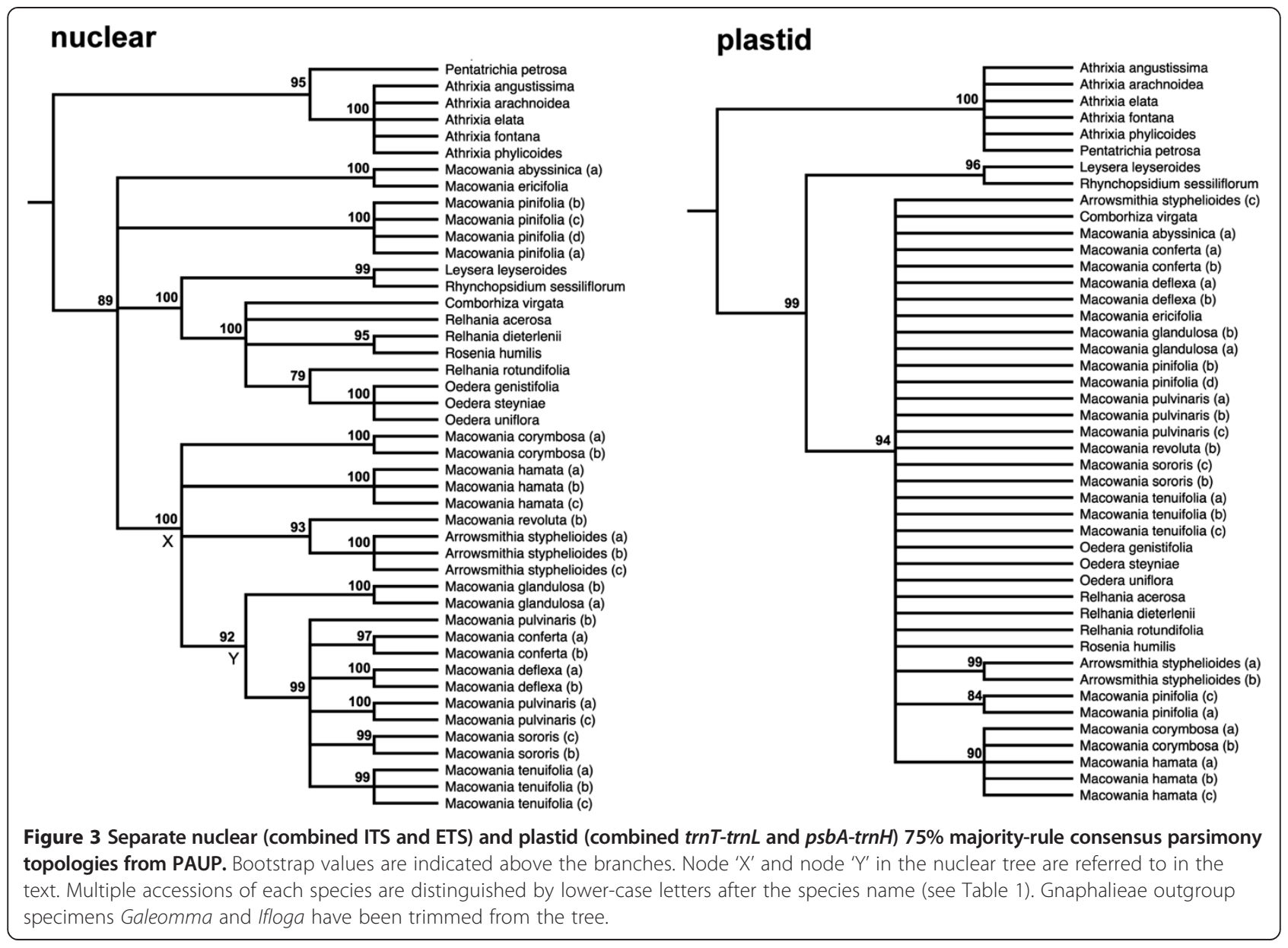

consisting of 1,051 characters, of which 104 (10\%) were parsimony-informative (Figure 3). Both the plastid and the nuclear gene trees independently recover Macowania as part of a clade containing the Relhania group of genera (represented here by Relhania, Oedera and Comborhiza). While the plastid topology neither rejects nor confirms the monophyly of Macowania, the nuclear gene tree resolves a clade comprising most species of Macowania (Node X; bootstrap percentage $(\mathrm{BS})=100$ ) and including Arrowsmithia. Within this clade, a group of Macowania species form a strongly supported subclade (Node Y; $\mathrm{BS}=99$ ). Multiple accessions of species were always recovered as monophyletic in the nuclear ribosomal tree, while only those from Arrowsmithia and M. pinifolia grouped together at the $75 \%$ BS level in the plastid tree. Conflict between nuclear and plastid partitions is observed only with regard to the placement of the outgroup taxa Leysera leyseroides and Rhynchopsidium sessiliflorum. Since relationships amongst the ingroup taxa showed no conflict, all genetic partitions were concatenated into a single matrix and analysed in combination.

The combined plastid and nuclear tree is well-resolved with a topology that closely resembles the individual nuclear topology (Figure 4), with no observed decrease in support values upon the inclusion of taxa sampled for only nuclear or plastid data. While the monophyly of the Relhania clade sensu Bergh \& Linder [43] is supported (Node E; MrBayes posterior probability $(\mathrm{PP})=1.0$, $\mathrm{BS}=100$; hereafter referred to as the "Relhania clade sensu lato"), the strength of this result is compromised by the rather limited outgroup sampling. The monophyly of the Relhania clade sensu lato has, however, been verified in other studies with more extensive outgroup sampling $[43,44]$. There is also support for a clade consisting of Macowania, Arrowsmithia, Relhania, Oedera, Leysera, Rhynchopsidium, Comborhiza and Rosenia (henceforth named "Relhania clade sensu stricto": Node F; PP $=1.0$, $\mathrm{BS}=100)$. Within the Relhania clade sensu stricto, $M$. pinifolia is placed as sister to a clade also comprising Relhania, Oedera, Leysera and relatives which is resolved as sister to the rest of Macowania. The placement of Macowania pinifolia in this position, however, lacks bootstrap support (Node G; PP $=0.97, \mathrm{BS}<75$ ). Though the position of the East African species within Macowania is unsupported, these are nevertheless confirmed as most closely-related to Macowania than to any other genus 


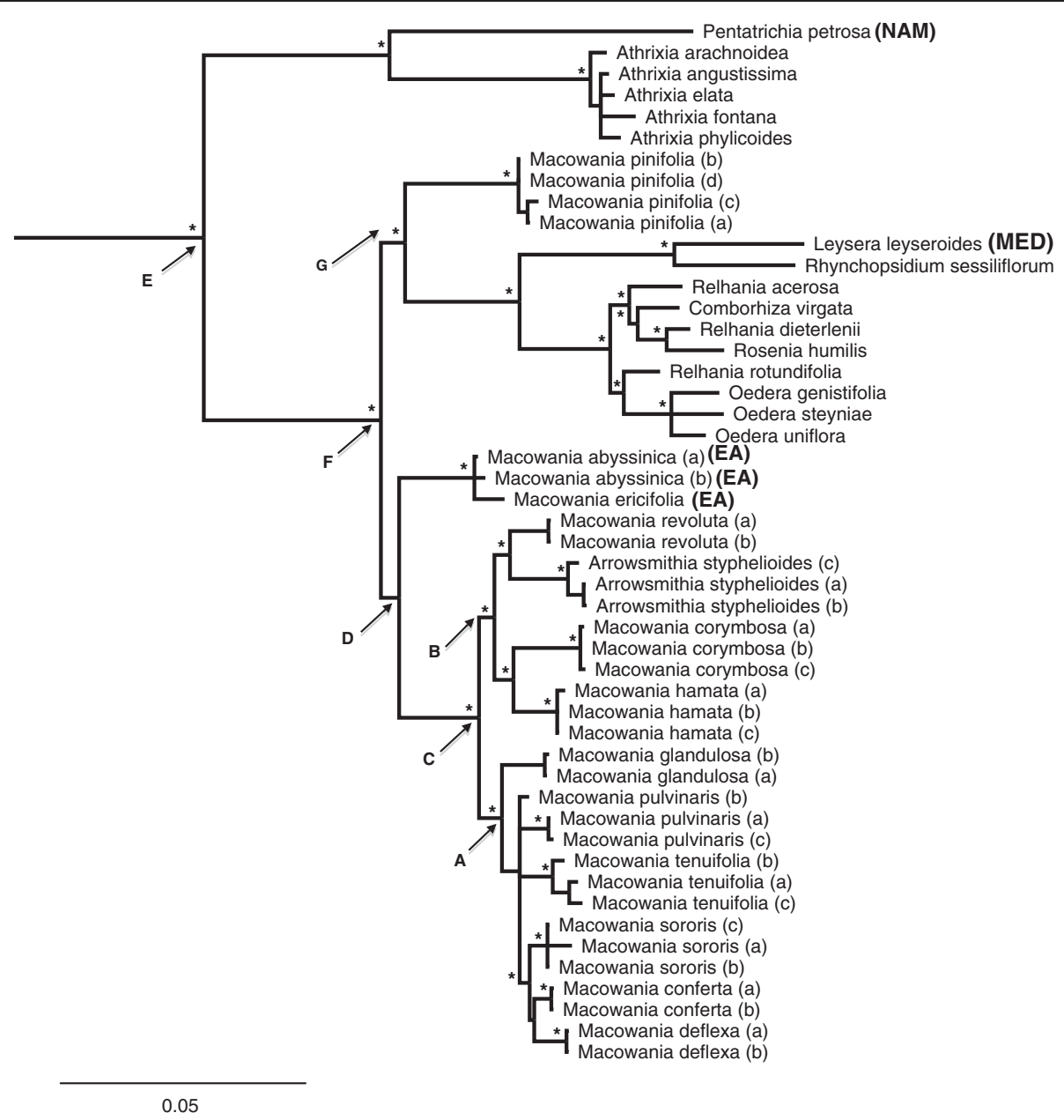

Figure 4 Combined nuclear (ITS and ETS) and plastid (trnT-trnL and psbA-trnH) 50\% majority-rule consensus Bayesian tree from the MrBayes analysis. Nodes supported by either parsimony bootstrap $(\geq 75 \%)$ or both Bayesian posterior probability $(\geq 0.95)$ and BEAST posterior probability $(\geq 0.95)$ are indicated with * above the relevant node. Note that node $\mathrm{G}$ is supported by Bayesian PP but not by BEAST PP). The support values for individual nodes A - G are reported in the text. Multiple accessions of each species are distinguished by lower-case letters after the species name (see Table 1). All species occur in South Africa or Lesotho (see Figure 1) except those with upper-case letters after the species: NAM (Namibia), NA (North Africa and/or Mediterranean and surrounds), EA (East Africa and Yemen). Gnaphalieae outgroup specimens Galeomma and Ifloga have been trimmed from the tree.

(their inclusion in the genus has also been confirmed by bootstrap, Bayesian and BEAST PP support in a subsequent analysis where near-complete sampling with multiple species accessions of the Relhania clade sensu lato and additional outgroups has been carried out by Bentley et al. unpubl. data). The South African members of Macowania are monophyletic (Node C; PP $=1.0, \mathrm{BS}=100$ ) subject to the inclusion of $A$. styphelioides. Within this 'core' Macowania clade, there is good support for two principal subclades, A and B. Clade B, which lacks support in the separate analyses, comprises $M$. revoluta (the type species), M. hamata, $M$. corymbosa and $A$. styphelioides $(\mathrm{PP}=1.0, \mathrm{BS}=97)$, while clade $\mathrm{A}(\mathrm{PP}=1.0$, $\mathrm{BS}=90$ ), which was also recovered in the nuclear gene tree, comprises M. tenuifolia, M. glandulosa, M. pulvinaris, $M$. deflexa, $M$. sororis and $M$. conferta. The species relationships within clade $\mathrm{A}$ are largely unresolved, but there is good support $(\mathrm{PP}=1.0, \mathrm{BS}=99)$ for a subclade containing $M$. conferta, $M$. deflexa and $M$. sororis. The monophyly of multiple accessions of each species in our tree is well-supported, with the exception of M. pulvinaris whose monophyly is not, however, contradicted.

\section{Divergence times and range overlap analysis}

At least in terms of supported nodes, the relaxed clock analysis (Table 2; BEAST tree provided in Additional file 1) yielded the same topology as the MrBayes analysis, with strong support for most nodes. The Relhania clade sensu lato and Relhania clade sensu stricto (Nodes E and F: [43]) both have high support $(\mathrm{PP}=1.0)$. The positions of M. pinifolia and the East African Macowania species (Node D), however, remain unresolved ( $\mathrm{PP}<0.95, \mathrm{BS}<75$ ). 
Table 2 BEAST median age estimates and 95\% highest posterior density (HPD) in millions of years before the present for nodes A - F (see Figure 4)

\begin{tabular}{lllll}
\hline Node & Clade & Median & 95\% HPD & PP \\
\hline A & Clade A & 3.6 & $1.20-7.00$ & 1.00 \\
B & Clade B & 4.2 & $1.51-7.87$ & 0.99 \\
C & Macowania crown age & 5.5 & $2.07-10.21$ & 1.00 \\
D & East African Macowania divergence & 9.4 & $3.79-16.22$ & 0.93 \\
E & Relhania clade sensu lato & 19.3 & $9.87-29.10$ & 1.00 \\
F & Relhania clade sensu stricto & 8.5 & $3.70-14.49$ & 1.00 \\
\hline
\end{tabular}

$\mathrm{PP}=$ posterior probability of the node in the BEAST analysis.

The core Macowania clade is well-supported ( $\mathrm{PP}=1.0)$, as are clades $\mathrm{A}(\mathrm{PP}=1.0)$ and $\mathrm{B}(\mathrm{PP}=0.99)$. Within clade A, the BEAST topology differs slightly from that produced by MrBayes, specifically with regard to the placement of $M$. tenuifolia. This species is placed sister to the rest of the members of clade A in BEAST, whereas MrBayes favours M. glandulosa in this position, although with no support. Internal relationships do not affect subsequent analyses as these rely solely on species membership of clade A and $\mathrm{B}$, not on their internal topologies.

Respectively, the median crown ages of the Relhania clade sensu lato (Node E) and Relhania clade sensu stricto (Node F) are estimated at 19.3 (95\% HPD 9.9 - 29.1) Ma and $8.5(3.7$ - 14.5) Ma (Table 2). Although poorly supported in all analyses, the node indicating the divergence of the East African Macowania species from the core Macowania clade (Node D) is dated to $9.4(3.8$ - 16.2) $\mathrm{Ma}$. The median crown age of the core Macowania clade (Node C) coincides with the Miocene/Pliocene boundary (5.5 Ma; $2.1-10.2 \mathrm{Ma}$ ), while those of clades A (Node A: 3.6 Ma, 1.2 - 7.0 Ma) and B (Node B: 4.2 Ma, 1.5 - $7.9 \mathrm{Ma}$ ) are both of Pliocene age, the error bars extending from the Late Miocene to Pleistocene. However, both dates have wide error margins which extend into the Miocene, indicating substantial uncertainty relating to their association with Pliocene uplift.

Within Macowania, most species pairs exhibit zero range overlap (Figure 5). Of the eight comparisons which do show overlap, only three involve species from the same subclade $(M$. revoluta with $A$. styphelioides [clade B], and M. glandulosa with both $M$. sororis and $M$. deflexa [clade A]). The overlaps involving $M$. glandulosa may partly be a function of using convex hulls, since both species have crescent-shaped ranges (Figure 1). Moreover, where M. glandulosa generally favours sandstone substrates at lower altitudes, the latter two associate with the basaltic substrates of the high scarp (Figure 1), such that the true levels of sympatry between these species pairs may be negligible. The same is not true for M. revoluta and A. styphelioides which have been observed to co-occur at a number of localities (Figure 1), in wet and dry micro-habitats respectively. A comparison of the proportion of pairwise range overlaps between clades $\mathrm{A}$ and $B$ revealed no significant differences between clades $(t=-0.3885, d f=19, P>0.05)$, signalling that range overlap levels are uniformly low in both clades.

\section{Potential adaptive differentiation}

Leaf and capitulum measurements provide a strong degree of morphological discrimination between species from clade B (symbols in shades of green), as indicated on the DFA biplot in Figure 6. Most members of clade $\mathrm{B}$, however, show some degree of overlap with one or more species from clade A (symbols in shades of purple and pink), and all clade A species overlap with at least one other member of their clade. Based on the traits examined, species in clade B thus exhibit greater morphological divergence than those in clade A. Consequently, the Mahalanobis' distances between species pairs within clade A are generally lower than those within clade $B$, and this difference is significant $(t=4.625, d f=14$, $\mathrm{P}<0.001)$ when compared against a randomly generated null. Of the 12 pairwise Mahalanobis' distance comparisons within clade A, all have values of 100 or less, with only three (the comparisons of $M$. glandulosa with $M$. deflexa, M. pulvinaris and M. sororis) being greater than 30. In contrast, all but one comparison within clade B yield distances greater than 100, and the highest value is 900; clearly morphological divergence in the traits of interest is much higher within this clade.

\section{Discussion}

To our knowledge, this study presents the first dated molecular phylogenetic study on a Drakensberg-nearendemic plant lineage as well as the first examination of geographic mode of speciation for the region. Phylogenetic data are fundamental to the study of lineage diversification, not only because they provide a (albeit tentatively) dated record of the successive speciation events underlying present-day species diversity, but also because they identify the bounds and membership of the lineage under study. Our data reveal Macowania to be non-monophyletic as currently circumscribed and, as such, inappropriate as a unit for evolutionary study. This is rectified, however, by the inclusion of the monotypic Arrowsmithia and the exclusion of M. pinifolia. MiocenePliocene uplift of the Drakensberg appears to have strongly influenced diversification within the MacowaniaArrowsmithia clade, because a strong signal of range allopatry points to geographical isolation as a key driver of speciation, and this diversification appears to have occurred post-uplift. We suggest that geographical isolation in Macowania is linked to Pliocene uplift and subsequent landscape erosion, these processes providing the necessary impetus for both non-ecological and ecological speciation. 


\begin{tabular}{|c|c|c|c|c|c|c|c|c|c|}
\hline \multirow{3}{*}{$\begin{array}{l}\text { M. revoluta } \\
\text { M. hamata } \\
\text { M. corymbosa }\end{array}$} & 0.98 & & & & & & & & \\
\hline & 0 & 0 & & & & & & & \\
\hline & 0 & 0 & 0 & & & & & & \\
\hline \multirow{3}{*}{$\begin{array}{l}\text { M. tenuifolia } \\
\text { M. pulvinaris } \\
\text { M. glandulosa }\end{array}$} & 0 & 0 & 0 & 0 & & & & & \\
\hline & 0 & 0 & 0 & 0 & 0 & & & & \\
\hline & 0 & 0 & 1 & 1 & 0 & 0 & & & \\
\hline \multirow{4}{*}{$\begin{array}{l}\text { M. sororis } \\
\text { M. deflexa } \\
\text { M. conferta }\end{array}$} & 0 & 0 & 1 & 0.16 & 0 & 0 & 0.55 & & \\
\hline & 0 & 0 & 0 & 0.95 & 0 & 0 & 1 & 0 & \\
\hline & 0 & 0 & 0 & 0 & 0 & 0 & 0 & 0 & 0 \\
\hline & 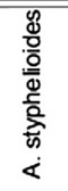 & $\begin{array}{l}\frac{\pi}{3} \\
\frac{\partial}{0} \\
\frac{2}{2} \\
\Sigma\end{array}$ & 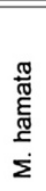 & $\begin{array}{l}\mathscr{8} \\
8 \\
\text { है } \\
8 \\
8 \\
\Sigma\end{array}$ & 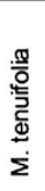 & 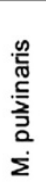 & $\begin{array}{l}\text { गु } \\
\frac{0}{5} \\
\overline{0} \\
\frac{\pi}{0} \\
\dot{\Sigma}\end{array}$ & 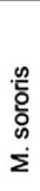 & 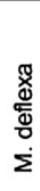 \\
\hline
\end{tabular}

Figure 5 Proportions of range overlap between species calculated using distributions estimated by convex-hull polygons. Comparisons which involve overlapping ranges (i.e. all non-zero values) are indicated in bold; a value of 1 indicates comparisons in which the range of the more narrowly-distributed species is completely embedded within that of the species with the larger range. Species names surrounded by the boxes belong to clade B of the 'core Macowania clade'.

\section{Taxonomic implications}

The current circumscription of Macowania does not reflect evolutionary relationships because the genus is paraphyletic if Arrowsmithia is excluded, and M. pinifolia is not found to be a member of the genus. Arrowsmithia is strongly supported as a member of the 'core' Macowania clade which includes the type, $M$. revoluta. Arrowsmithia and Macowania differ in several morphological features, interpreted as key generic characters by previous taxonomists [41,42]. Arrowsmithia has shorter, broader leaves than core Macowania members, with only slightly revolute margins and without a thickened, raised abaxial midrib. In contrast, all core Macowania species have linear leaves with strongly revolute margins and a substantially raised and thickened abaxial midrib, giving the leaf a characteristic channelled appearance. At first glance, the capitula of Arrowsmithia are identical to those of Macowania (Figure 2), but Hilliard \& Burtt [42] noted that the ray-floret achenes of Arrowsmithia have 20 ribs, compared with only 10 ribs in other members of Macowania. The only exception is $M$. revoluta which has 15 ribs [42] and was recovered as the sister to Arrowsmithia in our analysis.

A reconsideration of generic limits within the Macowania alliance is clearly required, and further questions relating to the monophyly of Macowania concern the status of the two East African species, M. abyssinica and M. ericifolia, as well as that of South African M. pinifolia. Although support for the relationship is poor, our analyses resolve $M$. abyssinica and $M$. ericifolia as sister to the 'core' Macowania clade (further substantiated by Bentley et al. unpubl. data), provisionally justifying their inclusion in the genus. In contrast to the situation for the East African species, the current data provide evidence against the continued inclusion of $M$. pinifolia in Macowania (supported by Bayesian PP, but not bootstrap or BEAST PP: Node G). This is congruent with the assessment of Hilliard \& Burtt [42], who suggest, mainly on the basis of leaf characters, that $M$. pinifolia is not closely related to the remainder of Macowania. Due to the limited Relhania clade outgroup sampling, a discussion of the relationships and non-monophyly of these lineages will be reserved for a future publication.

\section{Biogeographic history of Macowania in East Africa}

A likelihood-based ancestral area biogeographic reconstruction based on a phylogenetic hypothesis produced using multiple species accessions and near-complete species sampling (Bentley et al. unpubl. data) indicates that the Relhania clade sensu lato originated in southern Africa. The timing of diversification in Macowania, and its exclusive occupation of Afrotemperate habitats, suggests that dispersal into East Africa was recent, probably following Miocene uplift [15]. The dates are similar to estimates for Drakensberg - East African migrations in Disa [16] but earlier than those estimated for Euryops [71]. One interpretation by our data is that the occurrence of Macowania at altitudes above 2,300 $\mathrm{m}$ in the greater northern Ethiopian highlands (Ethiopia, Eritrea and Yemen) might be the consequence of a northward dispersal around $10 \mathrm{Ma}$ from a southern African centre of origin (though the error bars suggest substantial uncertainty in this estimate). Dispersal features in Macowania are weakly developed, consisting of small, light cypselas 


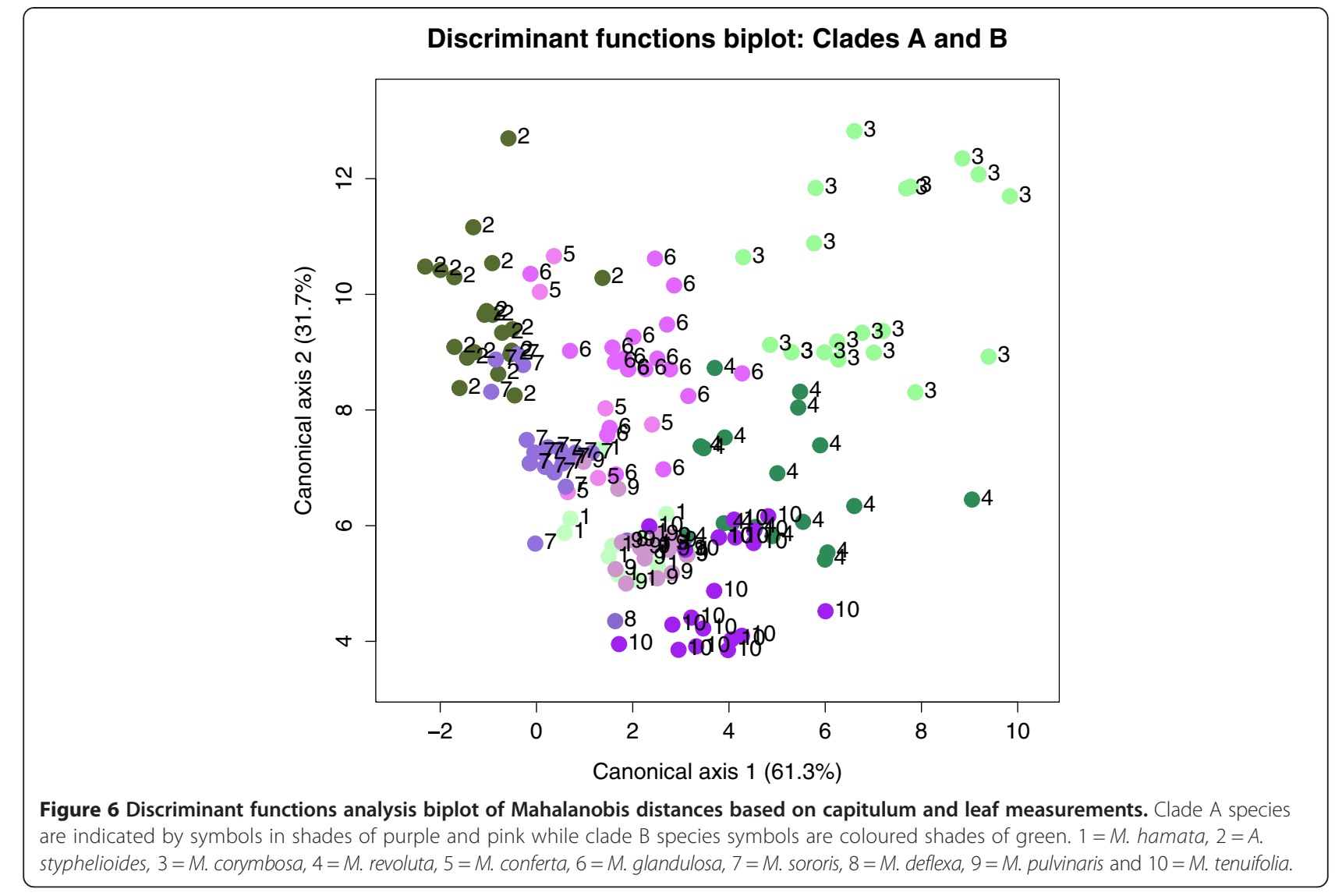

and a weak, feathery pappus with no specialised features to promote long-distance dispersal, and so species are likely to have low pappus-facilitated dispersibility. This, combined with the strict association of this genus with high altitudes and its apparent low dispersibility within South Africa, where most species are extremely localised, makes an expansive northward migration in Macowania an interesting prospect to unravel.

Uplifting of the East African Rift system started during the Eocene-Oligocene, attaining its greatest elevation during the Plio-Pleistocene interval [72-74]. One explanation for the East African disjunction in Macowania is that the topography of the high-altitude eastern leg of Africa was more uniform prior to this major uplift, facilitating northward dispersal. There is also a probable role for climate, with some authors [75-77] suggesting that wetter conditions prevailed along the eastern axis of Africa around $10 \mathrm{Ma}$, the onset of increased aridity and grassland expansion occurring later, at the PlioPleistocene boundary. If the ancestor of Macowania occupied multiple peaks along the eastern axis of Africa, then there would have been greater opportunity for the northeastward movement during wet periods, these peaks functioning as 'stepping stones' [16]. Subsequent aridification likely precipitated the extinction of the intervening populations, resulting in the isolation of the South African and East African populations, while PlioPleistocene changes in river systems [78] may also have played a role. Sustained isolation would have led to evolutionary divergence between the East African lineage and the ancestor of the 'core Macowania clade', the latter subsequently diversifying in the Drakensberg region.

\section{Pliocene uplift in the Drakensberg}

Our data are consistent with the scenario of a Drakensberg radiation in Macowania in response to recent tectonic uplift. Firstly, there is strong support for the monophyly of a clade of Drakensberg-endemic taxa (the 'core' Macowania clade), indicating a single radiation here. Secondly, our BEAST analysis dates the radiation of this clade to shortly after the major Pliocene uplift of the eastern Escarpment [11-14], its crown node age being estimated at $5.5 \mathrm{Ma}$, though this estimate carries wide error margins $(2.1-10.2 \mathrm{Ma})$. Our dates are, however, in line with earlier estimates of Drakensberg dispersals and radiations in Pentaschistis, Disa and Morea [16]. The bulk of the present-day species diversity is likely to have been generated more recently, with the crown nodes of the two principal subclades being dated to 3.6 Ma (clade 
A: 1.2 - 7.0 Ma) and 4.2 Ma (clade B: 1.5 - $7.9 \mathrm{Ma}$ ), consistent with a role for post-uplift scarp erosion.

Both subclades exhibit strong signals of range allopatry, suggesting that geographic isolation was important in speciation. Consistent with this idea, Macowania lacks specialised features which promote long-distance dispersal. Pronounced allopatry, in which distribution breaks coincide with erosion barriers, supports the idea that scarp erosion played a key role in the diversification of Macowania. This is best exemplified by the clade comprising $M$. sororis, $M$. deflexa and M. conferta. Species in this lineage consistently associate with high-altitude environments, all three being allopatric and for the most part very narrowly distributed. Macowania conferta is restricted to Ngeli Mountain, an isolated peak situated on the coastal plain about $85 \mathrm{~km}$ southeast of the main Drakensberg massif. Like Mount Currie, which supports the southeastern-most population of M. sororis, Ngeli is a relict fragment of a once-more extensive Drakensberg Escarpment, which has resisted the erosive forces that caused the Escarpment to retreat away from the presentday coastline. As such, the presence of Macowania on these peaks is likely also relictual, the disjunct nature of this distribution promoting vicariant divergence. Similarly, the deeply-incised Orange River canyon (Figure 1), the magnitude of its drainage accentuated by the increased westward tilt that Pliocene uplift conferred on the region [12], might explain the isolated and vicariant presence of M. pulvinaris on the opposing side of the river from other Macowania members, in western Lesotho and the northern reaches of the Eastern Cape Drakensberg. The presence of $M$. tenuifolia on isolated patches of Afrotemperate habitat in the Mpumalanga, Gauteng and Limpopo provinces might also be attributed to landscape erosion enabling divergence in allopatry. There are several floral elements linking this region with the KwaZuluNatal Drakensberg (e.g. Helichrysum subglomeratum, Selago procera) as well as with the escarpment to the north in the Zimbabwean highlands (e.g. H. swynnertonii, Aloe modesta; [79]), perhaps suggesting the historical connection of this land.

\section{Speciation of Macowania in the Drakensberg}

In the context of erosion-mediated vicariance, divergent selection may be critical in powering speciation (ecological speciation) or, somewhat more controversially [24,26], speciation may be powered by neutral processes alone (non-ecological speciation). Weak habitat and morphological differentiation between species within clade A suggest a primary role for isolation in species formation (non-ecological speciation). This is particularly evident for M. sororis, M. deflexa, M. conferta and M. pulvinaris, which exhibit no range overlap and very little morphological divergence, at least in terms of the traits sampled in this study. Taxonomically, these species are distinguished only by subtle characters of the peduncles and leaf-glands [80].

There is, however, some evidence for ecological divergence within clade A. Although M. glandulosa is broadly sympatric with $M$. sororis and $M$. deflexa (the only instances of sympatry in this clade), it shows some evidence of fine-scale ecological differentiation. Where the latter species inhabit scarp edge basalt substrates, $M$. glandulosa favours lower elevations, growing on the sandstone platforms that underlie the basalts [80]. Associated with this habitat shift is a morphological transition, M. glandulosa being the most morphologically-disparate species in clade A. Indeed, within Macowania as a whole, M. glandulosa is the only species possessing sunken leaf glands. Interestingly, M. glandulosa is itself disjunctly distributed, occupying two separate areas on the northeastern and southeastern arms of the Drakensberg Escarpment (Figure 1). There is some evidence of morphological divergence between the two regions, with the northernmost populations lacking glandular hairs on the leaves [80], indicating ongoing speciation in allopatry.

In contrast to clade $\mathrm{A}$, adaptive divergence appears to have played a greater role in stimulating speciation in clade B. Though leaf and capitulum measurements capture the stronger morphological differentiation between species within this clade, this is apparent even on the basis of cursory visual examination. For example, striking variation is apparent in leaf morphology, involucral bract coloration ( $M$. revoluta and $M$. corymbosa have brownedged bracts) and capitulum sexuality (in contrast to the typical gynomonoecious condition, $M$. revoluta has dioecious, and $M$. corymbosa, hermaphrodite capitula). These differences are also reflected in the taxonomic history of the group, this clade containing a species which has hitherto been treated as a separate genus (Arrowsmithia). Within clade B, morphological differentiation is most pronounced between $M$. revoluta and A. styphelioides. This differentiation is almost certainly ecologically motivated, these species being fully sympatric, although they occupy different micro-habitats within their shared range $(M$. revoluta grows in deep sandy soil in bogs, while A. styphelioides inhabits rocky slopes).

The other sister-pair within clade B, M. hamata and $M$. corymbosa, shows non-overlapping ranges, occurring exclusively on the southern and northern axes of the Drakensberg, respectively. Although these species show strong morphological divergence, their habitats are similar, suggesting a scenario of adaptive divergence in allopatry.

Ecologically-driven flowering time shifts also provide a potentially important mechanism which might power genetic isolation in sympatric species. Herbarium record data reveal little to no flowering time overlap between M. glandulosa (October - December) and M. sororis 
(January - July), and only marginal overlap between M. glandulosa and M. deflexa (December - January), suggesting that differences in phenology might influence the isolation of these species. Conversely, the data reveal that the flowering times of the sister-pair A. styphelioides (May - December) and M. revoluta (August - February) overlap; their ecological divergence thus cannot be attributed to differences in flowering time, suggesting that an alternative ecological explanation might explain their divergence in sympatry.

Although small flies have been observed visiting flowers of Macowania (N.Bergh, pers. obs.), little is known about the pollination mechanisms and breeding systems of these plants. Several studies (e.g. [81,82]) find pollinator diversity decreasing with increasing altitude, as well as a dominance of flies at higher altitudes. Galley et al. [16] suggest that pollinator specificity might play a role in promoting in situ speciation, suggesting that taxa with generalist pollination syndromes are unlikely to speciate as readily as those with specialist systems upon entering a new region. The same is suggested for Euryops [71], as, possibly like Macowania, this genus (also well-represented in the Afrotemperate regions) has a typical Asteraceae generalist pollination syndrome.

\section{Conclusions}

We sketch a scenario of post-uplift erosion-mediated speciation in Macowania. Although we are aware of no studies that explore the role of erosion as a stimulus for the diversification of the Drakensberg flora, a major limitation is that the scale of speciation in many Drakensberg clades has been modest, compromising our ability to infer strong patterns. Nevertheless, these ideas could be explored in the light of phylogenetic hypotheses of the larger endemic lineages, such as Helichrysum and Senecio (Asteraceae; 29 and 22 species, respectively); Erica (Ericaceae; 12 species), Delosperma (Mesembryanthemaceae; 12 species), Glumicalyx (Scrophulariaceae; 6 species), Rhodohypoxis (Hypoxidaceae; 6 species) and Huttonaea (Orchidaceae; 6 species) whose radiations, like that of Macowania, are hypothesised to have followed major uplift at the Miocene-Pliocene boundary (e.g. [17]). These findings may indicate general patterns of diversification applicable to other tectonically-influenced systems, including the high Andes, and suggest that post-uplift habitat production by erosive processes might be as much of a driver of speciation as the initial uplift itself.

\section{Availability of supporting data}

The datasets supporting the results of the plastid, nuclear and combined analyses is available in the TreeBASE repository, study ID $15214 \mathrm{http}: / /$ www.treebase. org/treebaseweb/search/study/summary.html?id=15214.
The Genbank accession numbers are provided in Table 1 of this manuscript.

\section{Additional file}

Additional file 1: BEAST MCC tree indicating 95\% HPD error bars on the nodes with a scalebar representing time in millions of years.

\section{Abbreviations}

BS: Bootstrap; PP: Posterior probability; ESS: Effective sample size; DAC: Drakensberg alpine centre.

\section{Competing interests}

The authors declare that they have no competing interests.

\section{Authors' contributions}

All authors were involved in the design of the study, field collection and the analyses as well as the drafting of the paper. JB performed the majority of molecular work and phylogenetic analyses. This study formed part of the MSC thesis of JB at the University of Cape Town under the supervision of NGB and GAV. All authors read and approved the final manuscript.

\section{Authors' information}

Joanne Bentley is a graduate student at the Department of Biological Sciences at the University of Cape Town (UCT). She is interested in using molecular tools to examine evolutionary processes.

Tony Verboom is an Associate Professor at the Department of Biological Sciences (UCT). His interests include the evolution and diversification patterns of the Greater Cape Flora and he specialises in phylogenetic methods of analysis to answer pertinent questions.

Nicola Bergh is a Researcher at the Compton Herbarium. Her focus is the evolutionary history of paper daisies in southern Africa.

\section{Acknowledgements}

We acknowledge M. Britton, V. Hoffmann, T. Moore and T. Trinder-Smith for their field assistance. C. McKune provided field assistance and photography. P. Armour and B. Armour (of Ingeli Forest Lodge) as well as T. A. Abbott are thanked for assistance in locating M. conferta. P. Lowry, A. Miya and several other Ezemvelo-KwaZulu-Natal reserve staff were extremely helpful during fieldwork. We further acknowledge the PRE, NU, GRA, BOL and PRU herbaria for providing herbarium specimens and allowing us to take material for DNA extraction. We also thank N. Hind and L. Csiba of KEW who provided DNA extractions of rare leaf material for the two East African members of the genus. Collecting permits were issued by the Cape Nature authorities, Ezemvelo-KwaZulu-Natal Parks board and Mpumalanga parks board, with access permission by several individual park managers. This study was funded by NRF Knowledge Fields Development (South African Biosystematics Initiative) grant 71072 awarded to N. Bergh and NRF MSc bursaries awarded to J. Bentley.

\section{Author details}

${ }^{1}$ University of Cape Town, Cape Town, South Africa. ${ }^{2}$ The Compton Herbarium, Kirstenbosch Research Centre, South African National Biodiversity Institute, Private Bag X7, Newlands, Cape Town, South Africa.

Received: 3 August 2013 Accepted: 10 February 2014

Published: 13 February 2014

\section{References}

1. Simpson BB: Pleistocene changes in the flora of the High Tropical Andes. Paleobiology 1975, 1:273-294

2. Burnham RJ, Graham A: The history of Neotropical vegetation: new developments and status. Ann Mo Bot Gard 1999, 86:546-589.

3. Hughes C, Eastwood R: Island radiation on a continental scale: exceptional rates of plant diversification after uplift of the Andes. Proc Natl Acad Sci U S A 2006, 103:10334-10339.

4. Bryson RW, Murphy RW, Lathrop A, Lazcano-Villareal D: Evolutionary drivers of phylogeographical diversity in the highlands of Mexico: a case study 
of the Crotalus triseriatus species group of montane rattlesnakes. J Biogeogr 2011, 38:697-710.

5. Bryson RW, García-Vázquez UO, Riddle BR: Diversification in the Mexican horned lizard Phrynosoma orbiculare across a dynamic landscape. Mol Phylogenet Evol 2012, 62:87-96.

6. Bryson RW, García-Vázquez UO, Riddle BR: Relative roles of Neogene vicariance and Quaternary climate change on the historical diversification of bunchgrass lizards (Sceloporus scalaris group) in Mexico. Mol Phylogenet Evol 2012, 62:447-457.

7. Xu T, Abbott RJ, Milne Rl, Mao K, Du FK, Wu G, Ciren Z, et al: Phylogeography and allopatric divergence of cypress species (Cupressus L.) in the Qinghai-Tibetan Plateau and adjacent regions. BMC Evol Biol 2010, 10:194.

8. Yang F-S, Qin A-L, Li Y-F, Wang X-Q: Great genetic differentiation among populations of Meconopsis integrifolia and its implication for plant speciation in the Qinghai-Tibetan Plateau. PloS one 2012, 7:e37196.

9. Myers N, Mittermeier RA, Mittermeier CG, Da Fonseca GA, Kent J: Biodiversity hotspots for conservation priorities. Nature 2000, 403:853-858

10. Luteyn JL, Churchill SP, Griffin D III, Gradstein SR, Sipman HJM, Gavilanes A: A checklist of plant diversity, geographical distribution, and botanical literature. New York: Botanical Garden; 1999.

11. King LC, King LA: A reappraisal of the Natal monocline. S Afr Geogr J 1959, 41:15-30.

12. Partridge TC, Maud RR: Geomorphic evolution of southern Africa since the Mesozoic. S Afr J Geol 1987, 90:179-208.

13. Partridge TC, Maud RR: Macro-scale geomorphic evolution of southern Africa. Oxf Monogr Geol Geophys 2000, 40:3-18.

14. Partridge TC: Of diamonds, dinosaurs and diastrophism: 150 years of landscape evolution in southern Africa. S Afr J Geol 1998, 101:167-184.

15. Carbutt C, Edwards TJ: The flora of the Drakensberg Alpine Centre. Edinburgh J Bot 2004, 60:581-607.

16. Galley C, Bytebier B, Bellstedt DU, Peter Linder H: The Cape element in the Afrotemperate flora: from Cape to Cairo? Proc R Soc B 2007, 274:535-543.

17. Carlson SE, Linder HP, Donoghue MJ: The historical biogeography of Scabiosa (Dipsacaceae): implications for Old World plant disjunctions. J Biogeogr 2012, 39:1086-1100.

18. Mcguire AF, Kron KA: Phylogenetic relationships of European and African Ericas. Int J Plant Sci 2005, 166:311-318.

19. Goldblatt P, Manning JC: Plant diversity of the Cape region of South Africa. Ann Mo Bot Gard 2002, 89:281-302.

20. Killick DJB: The Afro-alpine Region. In Biogeography and Ecology of Southern Africa. Edited by Werger MJA. The Hague: Springer Netherlands; 1978:515-560.

21. Lande R: Natural selection and random genetic drift in phenotypic evolution. Evolution 1976, 30:314-334

22. Wiens JJ: Speciation and ecology revisited: phylogenetic niche conservatism and the origin of species. Evolution 2004, 58:193-197.

23. Kozak KH, Weisrock DW, Larson A: Rapid lineage accumulation in a non-adaptive radiation: phylogenetic analysis of diversification rates in eastern North American woodland salamanders (Plethodontidae: Plethodon). Proc R Soc B 2009, 273:539-546.

24. Rundell RJ, Price TD: Adaptive radiation, nonadaptive radiation, ecological speciation and nonecological speciation. Trends Ecol Evol 2009, 24:394-399.

25. Schluter D: Ecological character displacement in adaptive radiation Am Nat 2000, 156:S4-S16.

26. Schluter D: Evidence for ecological speciation and its alternative. Science 2009, 323:737-741.

27. Mckinnon JS, Mori S, Blackman BK, David L, Kingsley DM, Jamieson L, Chou J, et al: Evidence for ecology's role in speciation. Nature 2004, 429:294-298.

28. Orr MR, Smith TB: Ecology and speciation. Trends Ecol Evol 1998, 13:502-506.

29. Partridge TC, Brink ABA: Gravels and terraces of the lower Vaal River basin. S Afr Geogr J 1967, 49:21-38.

30. Davies TA, Hay WW, Southam JR, Worsley TR: Estimates of Cenozoic oceanic sedimentation rates. Science 1977, 197:53-55.

31. Watson A, Williams DP: Early Pleistocene river gravels in Swaziland and their geomorphological and structural significance. Z Geomorphol 1985, 29:71-87. New Series.

32. Lageat $Y$, Robb JL: The relationships between structural landforms, erosion surfaces, and the geology of the Archean granite basement in the Barberton region, Eastern Transvaal. Trans Geol Soc S Af 1984, 87:141-159.

33. Gilchrist AR, Summerfield MA: Tectonic models of passive margin evolution and their implications for theories of long-term landscape development. In Process models and theoretical geomorphology. Edited by Kirkby MJ. Chichester, UK: Wiley; 1994:55-84.

34. Burke K, Gunnell Y: The African erosion surface: a continental-scale synthesis of geomorphology, tectonics, and environmental change over the past 180 million years. Mem Geol Soc Am 2008, 201.

35. Linder HP: The historical phytogeography of the Disinae (Orchidaceae). Bothalia 1983, 14:565-570.

36. White F: The Afromontane region. In Biogeography and ecology of southern Africa. Edited by Werger MJA. The Hague: Springer Netherlands; 1978:465-510.

37. Linder HP, Meadows ME, Cowling RM: History of the Cape Flora, The ecology of Fynbos: nutrients, fire and diversity. Cape Town: Oxford University Press; 1992:113-134.

38. Killick DJB: Drakensberg Alpine Region - Lesotho and South Africa. In Centres of Plant Diversity. Edited by Davis SD, Heywood VH. Oxford: Oxford University Press; 1994:257-260.

39. Van Wyk AE, Smith GF: Regions of Floristic Endemism in Southern Africa. Hatfield: Umdaus Press; 2001.

40. Carbutt $C$, Edwards TJ: The endemic and near-endemic angiosperms of the Drakensberg Alpine Centre. S Afr J Bot 2006, 72:105-132.

41. Kroner G: Systematische Studien im Umkreis von Athrixia Ker-Gawler (Asteraceae). Mitt Bot St Samml Munchen 1980, 16:1-267.

42. Hilliard OM, Burtt B: Notes on some plants of southern Africa. Notes Roy Bot Gard Edinburgh 1985, 42:230-233.

43. Bergh NG, Linder HP: Cape diversification and repeated out-of-southernAfrica dispersal in paper daisies (Asteraceae-Gnaphalieae). Mol Phylogenet Evol 2009, 51:5-18.

44. Ward J, Bayer RJ, Breitwieser I, Smissen R, Galbany-Casals M, Unwin M: Ch. 36: Gnaphalieae. In Systematics, Evolution and Biogeography of Compositae Edited by Funk VA, Susanna A, Stuessy TF, Bayer RJ. Vienna: International Association for Plant Taxonomy; 2009:539-588.

45. Galbany-Casals M, Andrés-Sánchez S, Garcia-Jacas N, Susanna A, Rico E, Montserrat Martínez-Ortega M: How many of Cassini anagrams should there be? Molecular systematics and phylogenetic relationships in the Filago group (Asteraceae, Gnaphalieae), with special focus on the genus Filago. Taxon 2010, 59:1671-1689.

46. Bergh NG, Trisos CH, Verboom GA: Phylogeny of the "Ifloga clade" (Asteraceae, Gnaphalieae), a lineage occurring disjointly in the Northern and Southern Hemisphere, and inclusion of Trichogyne in synonymy with Ifloga. Taxon 2011, 60:1065-1075.

47. Doyle J, Doyle JL: Genomic plant DNA preparation from fresh tissue-CTAB method. Phytochem Bull 1987, 19:11-15.

48. Gavel NJ, Jarrett RL: A modified CTAB DNA extraction procedure for Musa and Ipomoea. Plant Mol Biol Rep 1991, 9:262-266.

49. Bayer RJ, Puttock CF, Kelchner SA: Phylogeny of South African Gnaphalieae (Asteraceae) based on two noncoding chloroplast sequences. Am J Bot 2000, 87:259-272.

50. Baldwin BG, Markos S: Phylogenetic utility of the external transcribed spacer (ETS) of 18S-26S rDNA: congruence of ETS and ITS trees of Calycadenia (Compositae). Mol Phylogenet Evol 1998, 10:449-463.

51. Markos S, Baldwin BG: Higher-level relationships and major lineages of Lessingia (Compositae, Asteraceae) based on nuclear rDNA internal and external transcribed spacer (ITS and ETS) sequences. Syst Biol 2001, 26:168-183.

52. White TJ, Bruns T, Lee S, Taylor JW: Amplification and direct sequencing of fungal ribosomal RNA genes for phylogenetics. In PCR Protocols: A Guide to Methods and Applications. Edited by Innis MA, Gelfand DH, Sninsky JJ, White TJ. New York: Academic Press Inc; 1990:315-322.

53. Taberlet $P$, Gielly L, Pauton G, Bouvet J: Universal primers for amplification of three non-coding regions of chloroplast DNA. Plant Mol Biol 1991, 17:1105-1109.

54. Sang T, Crawford DJ, Stuessy TF: Chloroplast DNA phylogeny, reticulate evolution, and biogeography of Paeonia (Paeoniaceae). Am J Bot 1997 84:1120-1136.

55. Hall TA: BioEdit: a user-friendly biological sequence alignment editor and analysis program for Windows 95/98/NT. Nucleic Acids Symp 1999, 41:95-98.

56. Felsenstein J: Confidence limits on phylogenies: an approach using the bootstrap. Evolution 1985, 39:783-791.

57. Swofford DL: PAUP*. Phylogenetic analysis using parsimony (*and other methods). Version 4. Sunderland MA: Sinauer Associates; 1998.

58. Felsenstein J: Cases in which parsimony or compatibility methods will be positively misleading. Syst Zool 1978, 27:401-410. 
59. Alfaro ME, Holder MT: The posterior and the prior in Bayesian phylogenetics. Annu Rev Ecol Evol Syst 2006, 37:19-42.

60. Hillis DM, Bull Jj: An empirical test of bootstrapping as a method for assessing confidence in phylogenetic analyses. Syst Biol 2009, 59:182-192.

61. Huelsenbeck JP, Ronquist F: MRBAYES: Bayesian inference of phylogenetic trees. Bioinformatics (Oxford, England) 2001, 17:754-755.

62. Nylander JAA: MrModeltest V2, Programme distributed by author Evolutionary Biology Centre, Uppsala University; 2004:2 [http://www.abc.se/ nylander/mrmodeltest2/mrmodeltest2.html]

63. Akaike H: A new look at the statistical model identification. IEEE Trans Automat Contr 1994, 19:716-723.

64. Drummond AJ, Rambaut A: BEAST: Bayesian evolutionary analysis by sampling trees. BMC Evol Biol 2007, 7:214.

65. Graur D, Martin W: Reading the entrails of chickens: molecular timescales of evolution and the illusion of precision. Trends Genet 2004, 20:80-86.

66. Calenge $C$ : The package "adehabitat" for the R software: a tool for the analysis of space and habitat use by animals. Ecol Model 2006, 197:516-519.

67. Burgman MA, Fox JC: Bias in species range estimates from minimum convex polygons: implications for conservation and options for improved planning. Anim Conserv 2003, 6:19-28.

68. Fitzpatrick BM, Turelli M: The geography of mammalian speciation: mixed signals from phylogenies and range maps. Evolution 2006, 60:601-615.

69. Yates MJ, Verboom GA, Rebelo AG, Cramer MD: Ecophysiological significance of leaf size variation in Proteaceae from the Cape Floristic Region. Funct Ecol 2010, 24:485-492.

70. Mahalanobis PC: On the generalized distance in statistics. Proc Nat Instit Sci India 1936, 2:49-55.

71. Devos N, Barker NP, Nordenstam B, Mucina L: A multilocus phylogeny of Euryops (Asteraceae: Senecioneae) augments support for the "Cape to Cairo" hypothesis of floral migrations in Africa. Taxon 2010, 59:57-67.

72. Wolfenden E, Ebinger C, Yirgu G, Deino A, Ayalew D: Evolution of the northern Main Ethiopian rift: birth of a triple junction. Earth Planet SC Lett 2004, 224:213-228.

73. Chorowicz J: The East African rift system. J Afr Earth Sci 2005, 43:379-410

74. Sepulchre P, Ramstein G, Fluteau F, Schuster M, Tiercelin J-J, Brunet M: Tectonic uplift and Eastern Africa aridification. Science 2006, 313:1419-1423.

75. Sakai T, Saneyoshi M, Tanaka S, Sawada Y, Nakatsukasa M, Mbua E, Ishida H: Climate shift recorded at around $10 \mathrm{Ma}$ in Miocene succession of Samburu Hills, northern Kenya Rift, and its significance. Geol Soc London Spec Publ 2010, 342:109-127.

76. Levin NE, Quade J, Simpson SW, Semaw S, Rogers M: Isotopic evidence for Plio-Pleistocene environmental change at Gona, Ethiopia. Earth Planet Sc Lett 2004, 219:93-110.

77. Cerling TE, Harris JM, Macfadden BJ, Leakey MG, Quadek J, Eisenmann V, Ehleringer JR: Global vegetation change through the Miocene/Pliocene boundary. Nature 1997, 389:153-158.

78. Moore AE, Cotterill FPDW, Main MPL, Williams HB: The Zambezi River. In Large Rivers: Geomorphology and Management. Edited by Gupta A. England: Wiley; 2007:311-332.

79. Mucina L, Rutherford MC: The vegetation of South Africa, Lesotho and Swaziland. In Strelitzia 19. Edited by Mucina L, Rutherford MC. Pretoria: South African National Biodiversity Institute; 2006:585-614.

80. Hilliard OM, Burtt B: Macowania. Notes Roy Bot Gard 1976, 34:260-279

81. Arroyo MTK, Primack R, Armesto J: Community studies in pollination ecology in the high temperate Andes of Central Chile. I. Pollination mechanisms and attitudinal variation. Am J Bot 1982, 69:82-97.

82. Elberling $\mathrm{H}$, Olesen $\mathrm{JM}$ : The structure of a high latitude plant-flower visito system: the dominance of flies. Ecography 1999, 22:314-323.

doi:10.1186/1471-2148-14-27

Cite this article as: Bentley et al:: Erosive processes after tectonic uplift stimulate vicariant and adaptive speciation: evolution in an Afrotemperate-endemic paper daisy genus. BMC Evolutionary Biology 2014 14:27.

\section{Submit your next manuscript to BioMed Central and take full advantage of:}

- Convenient online submission

- Thorough peer review

- No space constraints or color figure charges

- Immediate publication on acceptance

- Inclusion in PubMed, CAS, Scopus and Google Scholar

- Research which is freely available for redistribution

Submit your manuscript at www.biomedcentral.com/submit
Biomed Central 